\title{
Article
}

\section{The role of ADAM17 during liver damage}

Al-Salihi, Mazin, Bornikoel, Anna, Zhuang, Yuan, Stachura, Pawel, Scheller, Jürgen, Lang, Karl S. and Lang, Philipp A.

Available at http://clok.uclan.ac.uk/38497/

Al-Salihi, Mazin ORCID: 0000-0002-3304-6967, Bornikoel, Anna, Zhuang, Yuan, Stachura, Pawel, Scheller, Jürgen, Lang, Karl S. and Lang, Philipp A. (2021) The role of ADAM17 during liver damage. Biological Chemistry, 402 (9). pp. 11151128. ISSN 1431-6730

It is advisable to refer to the publisher's version if you intend to cite from the work. http://dx.doi.org/10.1515/hsz-2021-0149

For more information about UCLan's research in this area go to http://www.uclan.ac.uk/researchgroups/ and search for <name of research Group>.

For information about Research generally at UCLan please go to http://www.uclan.ac.uk/research/

All outputs in CLoK are protected by Intellectual Property Rights law, including Copyright law. Copyright, IPR and Moral Rights for the works on this site are retained by the individual authors and/or other copyright owners. Terms and conditions for use of this material are defined in the policies page.

\section{CLoK}

Central Lancashire online Knowledge www.clok.uclan.ac.uk

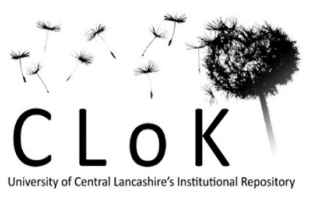




\section{Review}

\section{Mazin Al-Salihi, Anna Bornikoel, Yuan Zhuang, Pawel Stachura, Jürgen Scheller, Karl S. Lang and Philipp A. Lang* \\ The role of ADAM17 during liver damage}

https://doi.org/10.1515/hsz-2021-0149

Received February 15, 2021; accepted June 2, 2021

published online June 30, 2021

\begin{abstract}
A disintegrin and metalloprotease (ADAM) 17 is a membrane bound protease, involved in the cleavage and thus regulation of various membrane proteins, which are critical during liver injury. Among ADAM17 substrates are tumor necrosis factor $\alpha(\mathrm{TNF} \alpha)$, tumor necrosis factor receptor 1 and 2 (TNFR1, TNFR2), the epidermal growth factor receptor (EGFR) ligands amphiregulin (AR) and heparinbinding-EGF-like growth factor (HB-EGF), the interleukin-6 receptor (IL-6R) and the receptor for a hepatocyte growth factor (HGF), c-Met. TNF $\alpha$ and its binding receptors can promote liver injury by inducing apoptosis and necroptosis in liver cells. Consistently, hepatocyte specific deletion of ADAM17 resulted in increased liver cell damage following CD95 stimulation. IL-6 trans-signaling is critical for liver regeneration and can alleviate liver damage. EGFR ligands can prevent liver damage and deletion of amphiregulin and HB-EGF can result in increased hepatocyte death and reduced proliferation. All of which indicates that ADAM17
\end{abstract}

Mazin Al-Salihi and Anna Bornikoel contributed equally to this article.

*Corresponding author: Philipp A. Lang, Department of Molecular Medicine II, Medical Faculty, Heinrich Heine University, Universitätsstr. 1, D-40225 Düsseldorf, Germany, E-mail: langp@uniduesseldorf.de. https://orcid.org/0000-0001-5341-0407

Mazin Al-Salihi, Department of Molecular Medicine II, Medical Faculty, Heinrich Heine University, Universitätsstr. 1, D-40225 Düsseldorf, Germany; and School of Medicine, University of Central Lancashire, Preston, PR1 2HE, UK, E-mail: alsalihi@hhu.de

Anna Bornikoel, Yuan Zhuang and Pawel Stachura, Department of Molecular Medicine II, Medical Faculty, Heinrich Heine University, Universitätsstr. 1, D-40225 Düsseldorf, Germany, E-mail: anna_bornikoel@t-online.de (A. Bornikoel), yzhuang@bidmc.harvard.edu (Y. Zhuang), pawell.stachura@gmail.com (P. Stachura)

Jürgen Scheller, Department of Biochemistry and Molecular Biology II, Medical Faculty, Universitätsstr. 1, D-40225 Düsseldorf, Germany, E-mail: jscheller@uni-duesseldorf.de

Karl S. Lang, Institute of Immunology, Medical Faculty, University of Duisburg-Essen, Hufelandstr. 55, D-45147 Essen, Germany, E-mail: karlslang@gmail.com has a central role in liver injury and recovery from it. Furthermore, inactive rhomboid proteins (iRhom) are involved in the trafficking and maturation of ADAM17 and have been linked to liver damage. Taken together, ADAM17 can contribute in a complex way to liver damage and injury.

Keywords: ADAM17; IL-6; iRhom; liver damage; regeneration; TNF.

\section{Introduction}

Chronic liver disease and liver damage are a major public health challenge, accounting for more than 1 million deaths worldwide annually (Byass 2014; Koyama and Brenner 2017). Caused by viral infections, alcoholic and nonalcoholic liver disease, as well as auto-immune diseases affecting the liver or bile duct, hepatic inflammation and injury can result in liver fibrosis, cirrhosis, and even hepatocellular carcinoma (Byass 2014; Iwaisako et al. 2014; Koyama and Brenner 2017). Tissue damage can cause further immune activation, which can substantially promote liver inflammation, liver damage, and the development of pathologic changes such as liver fibrosis (Heymann and Tacke 2016; Robinson et al. 2016). Several cell death receptors have been associated with liver damage during liver disease (Luedde et al. 2014).

A disintegrin and metalloprotease 17 is a membrane bound protease, which cleaves membrane proteins to shed them from the plasma membrane (Lambrecht et al. 2018; Zunke and Rose-John 2017). Originally, ADAM17 was identified through its role in the proteolytic cleavage of membrane bound TNF $\alpha$ (Kriegler et al. 1988; Mohler et al. 1994), and named TNF $\alpha$ converting enzyme (TACE) (Black et al. 1997; Moss et al. 1997). Proteolytic cleavage by ADAM17 is involved in modulating several important signaling pathways, which also have been shown to play an important role in liver regeneration acting as mitogens for hepatocytes (Berasain et al. 2005a; Kiso et al. 2003; Michalopoulos 2007; Mitchell et al. 2005; Zarnegar et al. 1991). This review will focus on the role of ADAM17, its regulation, and ADAM17 dependent pathways during liver damage. 


\section{ADAM17 protease}

ADAM17 is comprised of an N-terminal signal peptide followed by a pro-domain, the metalloproteinase domain and a disintegrin-like domain, a cysteine-rich membrane proximal domain (MPD), and a unique Conserved Adam 17 Dynamic Interaction Sequence (CANDIS) region, succeeded by the stalk region, transmembrane helix and intracellular cytosolic tail (Düsterhöft et al. 2019). ADAM17 and ADAM10, which is closest to ADAM17 in structure and function, are atypical members of the ADAM family, as they contain the MPD region, instead of the cysteine-rich and EGF-like domain found in other ADAM family proteins (Takeda 2009). The MPD region and the CANDIS, which is not found in ADAM10, have been reported to be involved in the dimerization of ADAM17, while the CANDIS region has further been suggested to facilitate the interaction of ADAM17 with specific substrates, such as IL-6R (Düsterhöft et al. 2014; Riethmueller et al. 2016). Notably, in contrast to ADAM10, ADAM17 is not constitutively active, and multiple additional mechanisms for how ADAM17 activity is regulated have been brought forward (Grötzinger et al. 2017).

While ADAM17 transcription can be induced by inflammation and in neoplastic tissue, systemic over-expression was not found to result in upregulated levels of substrate shedding in vivo (Düsterhöft et al. 2019; Yoda et al. 2013). This indicated that ADAM17's proteolytic activity is regulated at the post-transcriptional level (Armstrong et al. 2006; Kornfeld et al. 2011; Ringel et al. 2006; Rzymski et al. 2012; Satoh et al. 2004, 2008). A detailed overview of ADAM17 activity, regulation and substrates is given elsewhere (Zunke and Rose-John 2017). Briefly, after ADAM17 is synthesized in the endoplasmic reticulum (ER), it requires various modifications before it becomes catalytically active. Activation of ADAM17 is mediated by cleavage of the pro-domain by furinlike proprotein convertases in the Golgi (Endres et al. 2003; Schlondorff et al. 2000; Wong et al. 2015) and phosphorylation of its cytosolic tail, relieving dimerization inhibition of ADAM17, via the ERK1/2 and p38 MAPK pathways (Figure 1) (Fan and Derynck 1999; Fan et al. 2003; Gechtman et al. 1999; Killock and Ivetic 2010; Lemjabbar-Alaoui et al. 2011; Saad et al. 2019; Schwarz et al. 2014; Xu and Derynck 2010). In the ER, the pro-protein is suggested to act as a chaperone for ADAM17, ensuring correct folding and processing, while protecting ADAM17 from degradation (Milla et al. 1999). In addition to this, the pro-protein has been reported to contribute to active site inhibition of ADAM17. Thus, cleavage of the pro-protein is important to release the inhibition of the catalytic site (Milla et al. 1999). Hence, the processing of ADAM17 has been suggested to contribute to its activity following phorbol 12-myristate 13-acetate (PMA) stimulation (Nagano et al. 2004; Soond et al. 2005). However, the absence of the cytoplasmic tail is dispensable for PMA mediated ADAM17 activation (Horiuchi et al. 2007b; Reddy et al. 2000). Consistently, rapid ADAM17 response following physiological stimuli requires its transmembrane domain, but not its cytoplasmic tail (Le Gall et al. 2010).

Additionally, the disintegrin domain has been suggested to play a role in the conformation of the ADAM17 protein, acting as a scaffold ensuring the C-shaped conformation and bridging between the catalytic and the MDP domain (Takeda et al. 2006). This may play a role in substrate

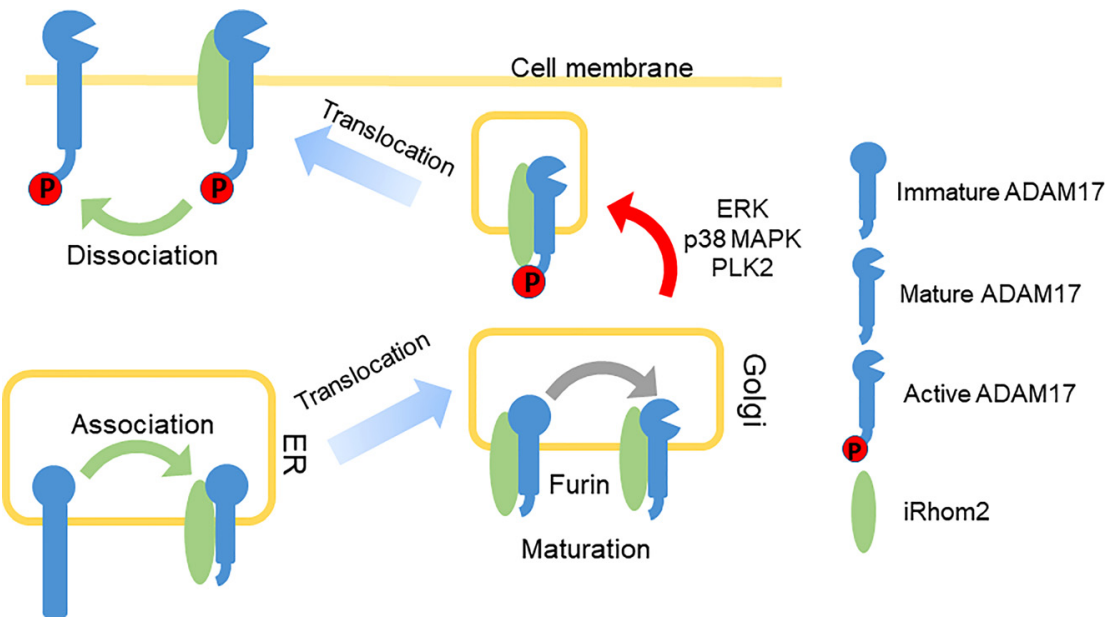

Figure 1: Schematic representation of the ADAM17 trafficking.

A simplified schematic illustrating that iRhom 2 creates a stable complex with ADAM17 in the Endoplasmic Reticulum, which leads to translocation of the complex to the Golgi apparatus and maturation of ADAM17 by removing the pro-domain by furin-like proprotein convertases. The mature form consists of a metalloprotease domain and cytosolic tail, which is next phosphorylated by several kinases, like ERK1/2, p38 MAPK and PLK2. The complex translocates to the cell membrane, where iRhom2 can dissociate from ADAM17. 
binding. Protein disulphide isomerase (PDI) has been demonstrated to inactivate ADAM17, by changing the conformation of the MDP region of ADAM17 from an open to a closed conformation (Düsterhöft et al. 2013, 2014; Lorenzen et al. 2012). In addition, this has also been suggested to affect the shedding activity of ADAM17, as only the open form of MDP binds to phospholipid phosphatidylserines, which are translocated to the outer leaflet of the cell membrane by scramblases in response to stimulation with PMA, for example. This interaction between phospholipid phosphatidylserines and open form MDP has been reported to result in a conformational change, which may contribute to the initialization of the shedding activity (Sommer et al. 2016a,b). Likewise, the CANDIS region has also been suggested to contribute to the conformational change in ADAM17 activating its shedding activity. The CANDIS region has been reported to contain an amphipathic helix, whose interaction with the cell membrane is enhanced in the presence of phosphatidylserine. High cholesterol in the cell membrane, on the other hand, has been found to counteract this interaction, thus indicating that cell membrane composition may be involved in the regulation of ADAM17 activity (Düsterhöft et al. 2015; Schütze et al. 2003; Tellier et al. 2006).

Dimerization of ADAM17 with $\alpha 5 \beta 1$ integrin via its disintegrin domain has been suggested to promote the binding of active site tissue inhibitor of metalloproteinase 3 (TIMP3) (Wisniewska et al. 2008), while decreasing the accessibility of the active site by steric hindrance (Bax et al. 2004; Huang et al. 2005). In addition to their role in trafficking ADAM17 from the ER to the Golgi, iRhoms have been demonstrated to play a role in the regulation of ADAM17 activation at the cell membrane, with ERK1/2-dependent phosphorylation of the cytoplasmic iRhom2 resulting in the release of mature ADAM17 and increased ADAM17 mediated shedding of TNF $\alpha$ (Adrain et al. 2012; Grieve et al. 2017; Maney et al. 2015).

Notably, ADAM17 deficient mice are perinatally lethal, exhibiting a specific developmental phenotype relating to epidermal growth factor receptor (EGFR) signaling (Peschon et al. 1998). These and other signaling pathways are modulated by ADAM17's proteolytic activity during liver damage (Figure 2).

\section{ADAM17 during liver damage}

ADAM17 deficient mice are perinatally lethal exhibiting development defects in the eye, hair and skin, which are associated with defects in transforming growth factor alpha (TGF $\alpha$ ) shedding (Peschon et al. 1998). However, the development of a hypomorph mouse model system, in which Adam 17 mRNA and protein levels are highly reduced, showed a critical role of ADAM17 in intestinal barrier function while mice were viable (Chalaris et al. 2010). Moreover, the generation of conditional ADAM17 knockout mice showed that myeloid specific deletion resulted in the protection of mice against LPS induced septic shock, with reduced serum TNFa levels following the challenge

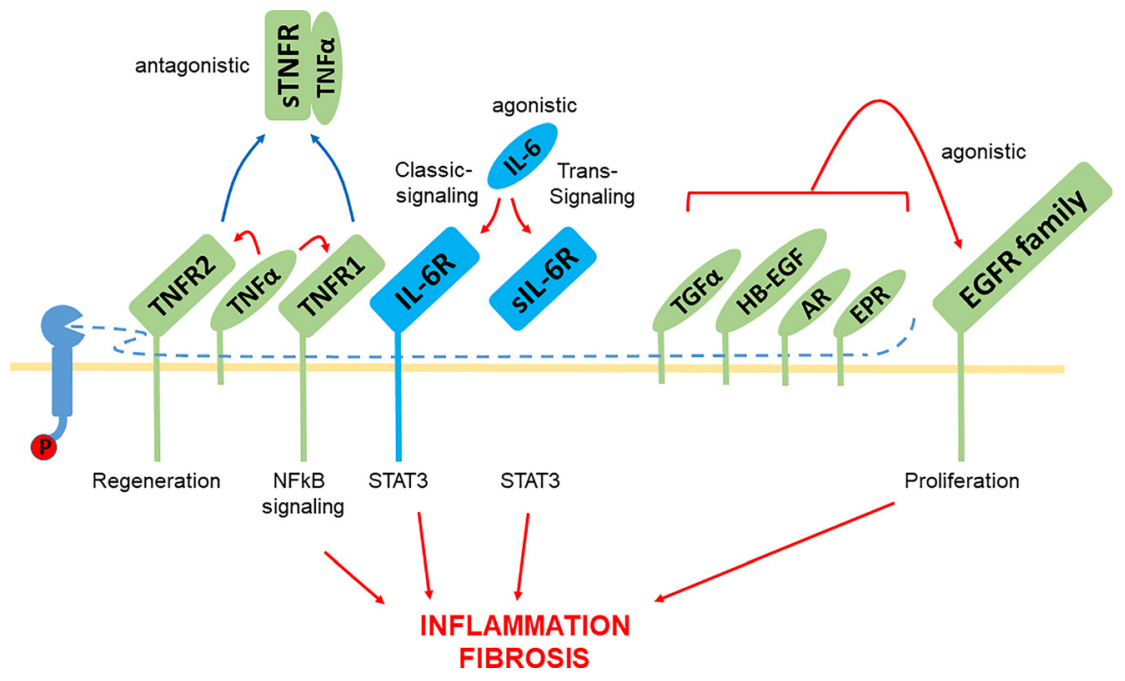

Figure 2: Schematic representation of the ADAM17 enzymatic activities.

A simplified schematic illustrates that ADAM17 can shed substrates from the cell surface, thereby controlling pro-inflammatory and proliferation pathways. Specifically, TNF $\alpha$ binds to TNFR1, which leads to activation of NF-KB and Jak2/STAT3 pathways respectively, whereas cleaving the receptors from the cell membrane can result in limited signaling. Other substrates include growth factors like TGF $\alpha$, heparinbinding EGF, amphiregulin, and epiregulin, which can bind to EGFR and induce proliferation. Shedding of IL-6R can result in IL-6 transsignaling via gp130. 
(Horiuchi et al. 2007a). Both, specific deletion of ADAM17 in either myeloid cells or hepatocytes resulted in reduced serum TNFa levels following stimulation with LPS and partial hepatectomy although liver regeneration appeared normal in these settings (McMahan et al. 2013). In turn, hepatocyte specific deletion of ADAM17 resulted in increased liver cell death following injection with anti-Fas antibodies, attributed to reduced TNFR1 and EGFR ligand shedding (Murthy et al. 2010). Consistently, the absence of TNFR1 reduced CD95 induced apoptosis in this setting (Murthy et al. 2010). Furthermore, adenoviral mediated expression of ADAM17 prevented liver cell damage during acetaminophen induced toxicity (Murthy et al. 2010). In turn, treatment of mice with $\alpha-1$ antitrypsin (AAT) showed increased survival following CD95 stimulation, which coincided with reduced activity of ADAM17 and decreased serum levels of TNF $\alpha$. Consistently, AAT treatment resulted in protection from liver failure following acetaminophen induced liver toxicity (Jedicke et al. 2014). These data suggest that there are overlapping functions of ADAM17.

ADAM17 maturation is triggered by co-factors such as iRhoms, which are inactive members of the rhomboid protease family (Al-Salihi and Lang 2020). The founding member rhomboid-1 was identified in Drosophila as a Golgi protein, which cleaves the EGF like ligand spitz, promoting its secretion (Lee et al. 2001; Urban et al. 2001). However, rhomboid proteins exist, which lack catalytic residues and are descriptively named inactive rhomboids (iRhom). There are two iRhom proteins in humans and mice, named iRhom1 and iRhom2, whereas in Drosophila there is only one iRhom member (Lemberg and Freeman 2007). IRhoms are unable to cleave traditional rhomboid substrates and iRhom deficient flies exhibit an extended sleep cycle, which has been associated with enhanced EGF receptor signaling (Zettl et al. 2011). While the single iRhom found in Drosophila induces ER associated ligand degradation (ERAD) and subsequent inhibition of EGFR signaling, both iRhom1 and iRhom2 have been shown to interact with ADAM17 (Li et al. 2015; Zettl et al. 2011). Deletion of both, iRhom1 and iRhom2 resembles the phenotype observed in ADAM17 deficient mice (Li et al. 2015). Moreover, examination of newborn iRhom 1 and 2 double knockout out mice, demonstrated a significant lack of mature ADAM17 in multiple tissues examined, including the liver. Notably, mature ADAM17 expression was also found to be significantly reduced in livers of iRhom2 knockout mice (Li et al. 2015). In turn, iRhom 1 and iRhom 2 single knockout mice are viable and fertile (Adrain et al. 2012; Li et al. 2015; Mcllwain et al. 2012; Siggs et al. 2012). These data suggest that iRhom1 and iRhom2 promote ADAM17 maturation in different compartments, which allows single knockout mice to overcome the severe phenotypes observed in ADAM17 deficient mice
(Peschon et al. 1998). In addition to ADAM17 activation, iRhom proteins may play a role in substrate specificity of ADAM17 (Maretzky et al. 2013). In mouse embryonic fibroblasts (MEF) iRhom 2 triggers, among others, shedding of the EGFR ligands HB-RGF, Amphiregulin, Epiregulin, but not TGF $\alpha$ (Maretzky et al. 2013). IRhoms can also regulate ADAM17 activation via their cytoplasmic tail. Deletion of the cytoplasmic tail results in increased ADAM17 activity and TNFR shedding, which triggers resistance to TNF mediated cell death (Maney et al. 2015). The mouse curly bare (cub) mutation, which deletes most of the cytoplasmic domain of iRhom2 showed alterations in EGFR signaling (Hosur et al. 2014; Siggs et al. 2014). Consistently, iRhom 2 gain of function mutations in its N-terminal cytoplasmic tail, identified in the inherited Tylosis with oesophageal cancer (TOC) syndrome, result in increased EGFR ligand and TNFR1 shedding (Blaydon et al. 2012; Brooke et al. 2014; Maney et al. 2015; Saarinen et al. 2012). Dissociation of iRhom 2 from ADAM17 takes place after phosphorylation of the cytoplasmic tail of iRhom2, which can occur at three different sites. Point mutations in each site downregulated the activity of ADAM17, while additive mutations resulted in complete loss of ADAM17 mediated shedding (Cavadas et al. 2017; Grieve et al. 2017). Moreover, coimmunoprecipitation of the extracellular iRhom 2 domain in MEFs upon stimulation with PMA demonstrated reduced interaction with ADAM17 compared to unstimulated cells. Grieve et al. concluded that phosphorylation of iRhom 2 on the cell membrane results in the dissociation from ADAM17 followed by increased catalytic activity (Grieve et al. 2017).

The regulation of ADAM17 via the interaction with iRhom 2 has been suggested to play a significant role in liver disease. Absence of iRhom 2 resulted in impaired shedding of TNF $\alpha$ and consequently reduced susceptibility towards LPS mediated liver damage and septic shock (McIlwain et al. 2012). Moreover, iRhom 2 was significantly upregulated following exposure to a mixture of air pollutants (PM2.5), which was accompanied by augmented levels of TNFR2, ADAM17 and TNF $\alpha$, hepatic steatosis, and dyslipidemia in the livers of WT mice. Markedly, however, PM2.5-induced liver damage and dyslipidemia were attenuated in the absence of iRhom2, while TNF $\alpha$ expression, as well as the expression of associated pro-inflammatory cytokines, were reduced in vitro (Ge et al. 2017). Moreover, mature ADAM17 expression and TNFR shedding is increased during bile duct ligation (BDL), a murine liver fibrosis model system (Sundaram et al. 2019). The absence of iRhom 2 resulted in decreased ADAM17 activation and reduced shedding of TNFRs following BDL. Consequently, hepatic stellate cell proliferation and liver fibrosis was increased in $i R h o m 2^{-/-}$ mice following BDL (Sundaram et al. 2019). Notably, myeloid and hepatocyte specific deletions of ADAM17 have 
also been associated with decreased TNF $\alpha$ serum levels and reduced TNFR1 shedding (McMahan et al. 2013; Murthy et al. 2010). Moreover, ursodeoxycholic acid (UDCA), used as a therapeutic agent for primary biliary cirrhosis and intrahepatic cholestasis, has not only been associated with regulating the expression of inflammatory cytokines, including TNF $\alpha$, but has also been demonstrated to improve BDL-induced cholestasis in mice by inhibiting ADAM17 activity and reducing sMet, with a similar trend for TNFa (Buryova et al. 2013; Ishizaki et al. 2008; Neuman et al. 2002). In addition, iRhom2 is a key regulator of inflammation driving non-alcoholic fatty liver disease (Xu et al. 2020). The absence of iRhom2 significantly alleviated insulin resistance, hepatic steatosis, and activation of inflammatory macrophages in iRhom2 knockout mice in response to high fat diet. This was associated with the interaction of hepatic iRhom2 with mitogen-activated protein kinase 7 (MAP3K7) and subsequent MAP3K7 phosphorylation, leading to NF- $\mathrm{KB}$ signaling and JNK/IRS1 signaling pathway activation, while impairing AKT/GSK3ß-associated insulin signaling (Xu et al. 2020). Similarly, hepatocyte specific deletion of ADAM17 has been shown to improve liver steatosis in a mouse model of NAFLD/NASH (Casagrande et al. 2017). Taken together, ADAM17 dependent signaling is critical during liver damage and in liver disease (Table 1).

\section{ADAM17-dependent pathways and their role during liver damage}

\section{TNF $\alpha$ signaling}

TNF $\alpha$ is a central cytokine during liver damage (Koyama and Brenner 2017; Luedde et al. 2014). Named for its anti-tumor activity, it was originally identified in the late ' 70 s and is the

Table 1: Overview of the ADAM17 dependent pathways on liver disease.

\begin{tabular}{|c|c|c|}
\hline Liver diseases & Examples for relevant ADAM17-regulated processes & Reference studies \\
\hline \multirow[t]{3}{*}{ Liver fibrosis and cirrhosis } & $\begin{array}{l}\text { TNF } \alpha \text { was associated with mediating NF-KB induced HSC } \\
\text { activation, as well as promoting HSC survival, thereby } \\
\text { contributing to liver fibrosis indirectly. }\end{array}$ & $\begin{array}{l}\text { (Osawa et al. 2013; Pradere et al. } \\
\text { 2013; Tarrats et al. 2011) }\end{array}$ \\
\hline & $\begin{array}{l}\text { Cleavage of MerTK, contributed to the activation of HSCs } \\
\text { and promoted liver fibrosis in NASH. }\end{array}$ & (Cai et al. 2020) \\
\hline & $\begin{array}{l}\text { Amphiregulin induced fibrogenic activity of hepatic stel- } \\
\text { late cells and promoted liver fibrosis. }\end{array}$ & $\begin{array}{l}\text { (Berasain et al. 2005b; McKee et al. } \\
\text { 2015; Santamaria et al. 2019) }\end{array}$ \\
\hline \multirow[t]{3}{*}{ Hepatocellular carcinoma } & $\begin{array}{l}\text { TNF signaling via NF-кB was reported to have a protective, } \\
\text { anti-apoptotic effect, which contributes to hepatocyte } \\
\text { carcinogenesis. }\end{array}$ & (Schwabe and Brenner 2006) \\
\hline & EGFR activation was shown to have a tumor-promoting role. & (Fuchs et al. 2014; Lanaya et al. 2014) \\
\hline & $\begin{array}{l}\text { Hepatic ADAM17 regulation by TIMP3 slowed } \\
\text { tumorgenesis. }\end{array}$ & (Casagrande et al. 2017) \\
\hline \multirow[t]{5}{*}{$\begin{array}{l}\text { Alcoholic and non-alcoholic fatty liver dis- } \\
\text { ease (NAFLD) as well as non-alcoholic } \\
\text { steatohepatitis (NASH) }\end{array}$} & $\begin{array}{l}\text { Augmented levels of EGFR ligand amphiregulin was } \\
\text { induced by fibrogenic activity of hepatic stellate cells, } \\
\text { driving liver fibrosis. }\end{array}$ & (McKee et al. 2015) \\
\hline & $\begin{array}{l}\text { ADAM17-mediated cleavage of MerTK was demonstrated } \\
\text { to contribute to the activation of HSCs, driving liver fibrosis } \\
\text { in NASH. }\end{array}$ & (Cai et al. 2020) \\
\hline & iRhom2 overexpressing mice showed inflammatory & (Casagrande et al. 2017; Xu et al. \\
\hline & aggravation mediated by NF- $\mathrm{KB}$ activation, whereas in the & 2020) \\
\hline & ADAM17 KO model, mice had alleviated hepatic steatosis. & \\
\hline \multirow[t]{2}{*}{ Viral hepatitis } & $\begin{array}{l}\text { TNF } \alpha \text { was shown to be crucial to mounting an appropriate } \\
\text { T-cell response to infection with hepatitis B virus. }\end{array}$ & $\begin{array}{l}\text { (Beyer et al. 2016; Kasahara et al. } \\
\text { 2003) }\end{array}$ \\
\hline & $\begin{array}{l}\text { TNF } \alpha \text { was associated with increased cell death via sup- } \\
\text { pression of NF-KB during viral infection. }\end{array}$ & (Park et al. 2012; Xu et al. 2014) \\
\hline \multirow[t]{3}{*}{ Liver regeneration } & $\begin{array}{l}\text { HGF and EGFR ligands, HB-EGF and amphiregulin acted as } \\
\text { mitogens for hepatocytes during liver regeneration. }\end{array}$ & $\begin{array}{l}\text { (Berasain et al. 2005a,b; Kiso et al. } \\
\text { 2003; Mitchell et al. 2005; Takemura } \\
\text { et al. 2013) }\end{array}$ \\
\hline & $\begin{array}{l}\text { IL- } 6 \text { was shown to have a transignaling role in liver } \\
\text { regeneration. }\end{array}$ & $\begin{array}{l}\text { (Fazel Modares et al. 2019; Jin et al. } \\
\text { 2006; Riethmueller et al. 2017) }\end{array}$ \\
\hline & $\begin{array}{l}\text { IL- } 6 \text { was shown to have a role in maintaining the biliary tree } \\
\text { in liver. }\end{array}$ & $\begin{array}{l}\text { (Demetris et al. 2006; Nozaki et al. } \\
\text { 2005) }\end{array}$ \\
\hline
\end{tabular}


founding member of a superfamily of cytokine-like molecules (Carswell et al. 1975; Green S Fau-Chiasson et al.). Along with their cognate receptors, the TNFR superfamily control signaling pathways in immunity and disease (Dostert et al. 2019; Kondylis and Pasparakis 2019). TNF $\alpha$ can induce signaling via two cognate receptors TNFR1 and TNFR2. TNF $\alpha$ has been shown to promote liver damage during toxic liver damage (Yin et al. 1999). Injection of TNF $\alpha$ can cause severe liver damage and septic shock when applied in combination with D-Galactosamine (D-Gal), which is dependent on TNFR1 (Luedde et al. 2014). Consistently, TNFR1 deficient mice are protected from liver injury and septic shock following lipopolysaccharide (LPS) challenge (Pfeffer et al. 1993; Rothe et al. 1993). TNFR1 is ubiquitously expressed and can be activated by both shed and membrane bound TNF $\alpha$. TNFR2 on the other hand is expressed in a more limited fashion on immune, neuronal, cardiac, endothelial and stem cells and binds membrane bound TNF $\alpha$ with higher affinity (Dostert et al. 2019). Notably, ADAM17 can cleave membrane bound TNF $\alpha$ into its soluble form as well as the binding receptors TNFR1 and TNFR2 (Peschon et al. 1998). Accordingly, ADAM17 contributes to soluble TNFo's systemic effects. Conversely, shedding of the TNFRs reduces TNFR1 signaling, and resulting soluble TNFRs can bind to TNF $\alpha$ thereby reducing its biological activity. Therefore, depending on the balance of TNF $\alpha$ versus TNFR cleavage and the predominant cell on which this happens, ADAM17 can have opposite effects on liver damage and fibrosis. Furthermore, the TNF pathway once activated also has dual outcomes when it comes to hepatocyte death and proliferation.

The binding of TNFa to TNFR1 results in a conformational change exposing the death domain of TNFR1. This leads to the recruitment of the adaptor protein TNFR1associated death domain (TRADD) via the interaction of the death domains. The interaction of TNFR1 and TRADD provides an assembly scaffold for the recruitment of further adaptor molecules, resulting in the formation of complexes I and II and subsequent induction of TNF signaling. Complex I consists primarily of the receptor itself, the adaptor protein TRADD, TNFR-associated factor 2 (TRAF-2), cellular inhibitors of apoptosis 1 and 2 (cIAP1/2), linear ubiquitin chain assembly complex (LUBAC) and receptor-interacting serine/threonine-protein kinase 1 (RIPK1). Complex II is comprised of three distinct, Fas-associated death domain (FADD) and long isoform of FLICE-like inhibitory protein $\left(\right.$ FLIP $\left._{\mathrm{L}}\right)$ containing sub complexes, IIa-c. Phosphorylation, ubiquitination and de-ubiquitination of RIPK1 controls whether TNF $\alpha$ binding to TNFR1 results in signaling via complex I or complex II (Feoktistova et al. 2011; Wang et al. 2008; Yu and Cleveland 2018). The TNF $\alpha$-TNFR1 signaling pathway can induce several different cellular responses including inflammation, apoptosis and necrosis by activating gene transcription in downstream signaling pathways such as NF-kB, JNK, and p38.

Complex I activates downstream NF-kB signaling resulting in the expression of pro-inflammatory and prosurvival genes (Dostert et al. 2019; Hsu et al. 1995, 1996; Kondylis and Pasparakis 2019; Ting et al. 1996). In turn, NF$\kappa B$ inhibition and complex II formation results in cell death and induces tumor regression (Dostert et al. 2019; Fulda 2015; Kondylis and Pasparakis 2019; Xie et al. 2016). The mode of cell death induced depends on which type of complex II is formed and the presence or absence of active caspase 8. In complex II FLIP $_{\mathrm{L}}$ mirrors caspase 8 and is catalytically inactive, but forms catalytically active heterodimers, which have a reduced activity and altered targets compared to caspase 8 homodimers (Dostert et al. 2019; Pop et al. 2011). While the short isoforms ( $\mathrm{S}$ and $\mathrm{R}$ ) bind to caspase 8 and inhibit its activation (Golks et al. 2005; Irmler et al. 1997). Complexes IIa and IIb induce apoptosis, are caspase 8 dependent and contain either TRADD or RIPK1 respectively. Absence of active caspase 8 results in necroptosis (Holler et al. 2000; Vercammen et al. 1998; Zhang et al. 2009). Caspase 8 is an initiator caspase; when active, it triggers a downstream cascade of caspase cleavage, leading to activation of effector caspases such as caspase 3, ultimately leading to apoptosis (Dostert et al. 2019; Stennicke et al. 1998). Consistently, TNF $\alpha$ expression levels correlate with active caspase 3 in patient cohorts suffering from hepatitis $C$ virus infection, which can increase the sensitivity towards TNF $\alpha$ mediated cell death (Park et al. 2012; Walsh et al. 2004). TNF $\alpha$ promotes chronic viral infection and hepatitis in murine viral infection model systems (Beyer et al. 2016; Suresh et al. 2005; Xu et al. 2014; Zhuang et al. 2020), and Hepatitis B virus infection sensitizes hepatocytes towards TNF $\alpha$ mediated cell death (Jia et al. 2015). In contrast to Complexes IIa and IIb, Complex IIc, also known as the necrosome, depends on RIPK1, 3 and mixed lineage kinase domain-like (MLKL) to induce necroptosis via the insertion of MLKL into the plasma membrane creating an ion channel (Cai et al. 2014; Dostert et al. 2019; Galluzzi et al. 2014; Kondylis and Pasparakis 2019; Wang et al. 2008, 2014; Weber et al. 2018). Notably, complex II formation can occur independently of its role in cell death and inflammation. This last has been linked to chromosomal stability, suggesting a possible mechanism relating loss of caspase 8 to hepatocellular carcinoma (HCC) among other cancers (Liccardi et al. 2019; Soung et al. 2005).

During liver fibrosis, TNF $\alpha$ produced by Kupffer cells and neutrophils induces Hepatic stellate cell (HSC) activation and proliferation. Specifically, TNF $\alpha$ and LPS 
promote proliferation and survival of HSCs by activating NF- $\mathrm{kB}$ and down-regulating pro-apoptotic genes (Gandhi 2017; Osawa et al. 2013; Seki et al. 2007). Accordingly, liver damage and fibrosis were decreased in TNFR1 KO mice and TNFR1\&2 double knockout mice compared to wild-type or single TNFR2 KO mice in a murine model system of fibrosis, suggesting TNF-TNFR1 but not TNFR2 is critical for HSC activation and liver fibrosis (Tarrats et al. 2011).

\section{IL-6 receptor signaling}

IL-6 signaling is induced by IL-6, secreted during the inflammatory response, binding to its non-signal transducing $\alpha$-receptor IL-6R and the signaling receptor gp130 (Tanaka et al. 2014). IL-6 signaling can also be induced in cells lacking membrane bound IL-6R, albeit IL- 6 cannot bind to gp130 in the absence of IL-6R. However, IL- 6 cannot bind to gp130 on its own, but rather gp130 binds the IL-6/IL-6R complex (Schmidt-Arras and Rose-John 2016). This signaling requires the shedding of membrane bound IL-6R. Active ADAM17 and ADAM10 can cleave IL-6R, resulting in soluble IL-6R (sIL-6R) (Müllberg et al. 1993; Riethmueller et al. 2017). Accordingly, sIL-6R can still bind IL-6 and gp130 on cells, which lack IL-6R, and induce gp130 mediated signaling, socalled IL-6 trans-signaling (Mackiewicz et al. 1992). IL-6 expression during the inflammatory response to injury, results in the induction of acute phase proteins such as C-reactive protein and fibrinogen. In the liver, IL-6, expressed by neutrophils, monocytes and macrophages, is a major force driving the expression of acute phase proteins (Schmidt-Arras and Rose-John 2016). Aside from its role prominent as a potent pro-inflammatory cytokine, IL-6 has been reported to play a critical role in liver regeneration. Hepatectomy in rats results in increased TNF $\alpha$ levels, succeeded by significantly increased IL- 6 expression (Trautwein et al. 1996). Consistently, B cells and macrophages triggered IL-6 expression in mice following partial hepatectomy (Behnke et al. 2018). In the absence of IL-6 signaling tissue regeneration after partial hepatectomy was impaired (Cressman et al. 1996; Fazel Modares et al. 2019). Likewise, inhibition of IL-6 signaling resulted in increased liver damage in response to carbon tetrachloride $\left(\mathrm{CCL}_{4}\right)$ induced liver damage (Gewiese-Rabsch et al. 2010). Moreover, liver injury was exacerbated by inhibition of IL-6 signaling in a nonalcoholic steatohepatitis (NASH) model (Yamaguchi et al. 2011). The absence of gp130 - abolishing all IL-6-type cytokine signaling - resulted in increased liver damage following BDL, which was associated with increased bacterial burden (Wuestefeld et al. 2005). Moreover, lack of IL-6, gp130, and
STAT3 signaling in the liver promoted establishment of steatohepatitis (Kroy et al. 2010).

While classical signaling via the membrane-bound IL-6 receptors is associated with the inflammatory role of IL-6, IL-6 trans-signaling has been suggested to play a major role in liver regeneration. Hyper-IL- 6 is a fusion protein between IL-6 and soluble IL-6R, which stimulates trans-signaling in gp130 expressing cells (Schmidt-Arras and Rose-John 2016). Mice expressing Hyper-IL-6 exhibited hepatocellular hypertrophy and accelerated liver regeneration following partial hepatectomy (Peters et al. 2000). Consistently, in a mouse model exhibiting only IL-6 trans-signaling, liver regeneration following partial hepatectomy was comparable to control animals (Fazel Modares et al. 2019). Furthermore, administration of Hyper-IL-6 during toxic liver injury could alleviate liver damage and promote hepatocyte proliferation (Galun et al. 2000). Taken together, these findings suggest a prominent role of IL- 6 trans-signaling, triggered by ADAM17 IL-6R cleavage, during liver regeneration. Reduced IL6-trans-signaling might result in increased liver damage and prolonged injury.

\section{EGFR signaling}

ADAM17 can cleave a variety of EGFR ligands including amphiregulin, heparin-binding-EGF-like growth factor, epiregulin, TGF $\alpha$ and epigene (Sahin and Blobel 2007; Sahin et al. 2004; Sigismund et al. 2018). Conditional deletion of EGFR on hepatocytes was associated with increased liver transaminases and reduced survival following partial hepatectomy (Natarajan et al. 2007). Consistently, mice with hepatic deletion of EGFR showed increased liver damage and cancer formation following DEN treatment (Lanaya et al. 2014). In turn, macrophage specific deletion of EGFR caused reduced cancer growth (Lanaya et al. 2014). Treatment with the EGFR inhibitor erlotimib alleviated the establishment of liver fibrosis and the development of hepatocellular carcinoma (Fuchs et al. 2014). In turn, ectodomain shedding of EGFR ligands and TNFR1 can critically regulate acute liver damage (Murthy et al. 2010). Conditional deletion of HB-EGF results in increased liver injury following acute toxic hepatitis (Takemura et al. 2013). Furthermore, overexpression of HB-EGF results in aggravated liver fibrosis following chronic liver injury (Guo et al. 2017). Deletion of amphiregulin prevented hepatocyte proliferation following partial hepatectomy. Furthermore, pretreatment with amphiregulin could prevent liver damage following CD95 stimulation (Berasain et al. 2005b). Consistently, amphiregulin deficient mice showed increased liver injury during bile duct ligation 
(Santamaria et al. 2019). Collectively, these reports hint to a rather protective role of EGFR ligands and thus a potentially prominent role for ADAM17 shedding during liver injury but cell, substrate, and context specific effects might apply.

\section{Other substrates}

Likewise, the receptor for hepatocyte growth factor, c-Met has been reported to play a significant role in liver development and regeneration (Chalupský et al. 2013). Chalupský et al. demonstrate that ADAM17 along with ADAM10 are involved in releasing the soluble form of the c-Met receptor, sMet from the cell surface in human hepatocellular HepG2 and hepatic stellate cell LX2 lines, while postulating a dominant role for ADAM17. Moreover, serum levels of sMET in a hepatobiliary obstruction mouse model correlated with the level of hepatic injury, expression of established markers of liver damage including alanine aminotransferase (ALT), aspartate transaminase (AST), alkaline phosphatase (ALP), and total bilirubin, as well as with subsequent regeneration (Chalupský et al. 2013). Hepatocyte specific, post partum deletion of c-Met resulted in increased hepatocyte apoptosis and reduced proliferation following transfer experiments (Kaldenbach et al. 2012). Consistently, hepatocyte specific deletion of c-Met resulted in fulminant liver damage and lower hepatocyte proliferation following bile duct ligation (BDL) (Giebeler et al. 2009).

\section{ADAM17 as a therapeutic target}

Since its discovery as a protease involved in the activation of the TNF pathway, ADAM17 has been a focal point of research aiming to find new therapeutics for inflammatory diseases (Calligaris et al. 2021). However, due to its involvement in the regulation of multiple signaling pathways, with over 80 different substrates aside from TNF reported, and the similarity of its catalytic domain to ADAM10, which plays an important role in vascularisation, cell proliferation and differentiation, and several other metalloproteinases, targeting ADAM17 has proven difficult (Calligaris et al. 2021; Maskos et al. 1998; Riethmueller et al. 2016; Wetzel et al. 2017; Zunke and Rose-John 2017). Initial drugs designed to target ADAM17 activity demonstrated severe side effects, including serious hepatotoxicity, outweighing their therapeutic benefits (Calligaris et al. 2021; Moss et al. 2008; Rossello et al. 2016). Thus, the risk of deregulating numerous physiologically relevant processes and the broad expression of ADAM17 throughout the body, pose a caveat for targeting ADAM17 therapeutically (Calligaris et al. 2021; Zunke and Rose-John 2017).
Nevertheless, several promising approaches have been explored recently and are reviewed in more detail by Calligaris et al. (2021). These include the use of more specific small molecules, manipulating the selectivity of endogenous inhibitors of ADAM17, as well as targeting the ancillary domains of ADAM17 or regulators, that are specific and essential for ADAM17 activation, such as iRhoms (Calligaris et al. 2021). For example, Wong et al. developed a stable form of the autoinhibitory pro-domain of ADAM17 (or TACE pro-domain), TPD, which demonstrated promising attenuation of ADAM17mediated disease in models of sepsis, rheumatoid arthritis (RA) and inflammatory bowel disease as well as in RA patients (Wong et al. 2016).

Notably, targeting iRhom2 therapeutically is a particularly promising route: Not only is iRhom2 specific for ADAM17, but also it carries the advantage that, iRhom1 can substitute for the loss of iRhom2-mediated regulation of ADAM17. At the same time, using iRhom2 as a therapeutic target could regulate several pro-inflammatory ADAM17-mediated factors, including IL-6 signaling (Calligaris et al. 2021).

\section{Concluding remarks}

ADAM17 substrates play a critical role during liver damage in various model systems. Furthermore, data from conditional ADAM17 deficient mice corroborate the significance of ADAM17 during liver damage. Myeloid deletion of ADAM17 resulted in reduced soluble TNFa production. In turn, hepatocyte specific deletion resulted in increased liver damage resulting from reduced shedding of TNFRs. Furthermore, IL-6 trans-signaling is important for liver regeneration and hepatocyte proliferation. Accordingly, cell type specific regulation of ADAM17 is critical to orchestrating liver regeneration and liver damage. In addition, adaptor molecules such as iRhoms might cause cell specific or substrate specific ADAM17 activity and thus could critically regulate liver damage during disease model systems. However, further characterization of ADAM17 in different cell subsets is required to fully understand the complete picture of ADAM17 during liver damage and disease. This is particularly important to further explore ADAM17 or its regulators as a therapeutic target.

Author contributions: A.B., M.A., Y.Z., P.S., J.S., K.S.L., and P.A.L wrote the paper.

Research funding: This study was supported by the German Research Council (SFB974, RTG1949) and the Jürgen Manchot Graduate School MOI.

Conflict of interest statement: The authors declare no conflicts of interest regarding this article. 


\section{References}

Adrain, C., Zettl, M., Christova, Y., Taylor, N., and Freeman, M. (2012). Tumor necrosis factor signaling requires iRhom 2 to promote trafficking and activation of TACE. Science 335: 225-228.

Al-Salihi, M.A. and Lang, P.A. (2020). iRhom2: an emerging adaptor regulating immunity and disease. Int. J. Mol. Sci. 21: 6570.

Armstrong, L., Godinho, S.I., Uppington, K.M., Whittington, H.A., and Millar, A.B. (2006). Contribution of TNF-alpha converting enzyme and proteinase- 3 to TNF-alpha processing in human alveolar macrophages. Am. J. Respir. Cell Mol. Biol. 34: 219-225.

Bax, D.V., Messent, A.J., Tart, J., van Hoang, M., Kott, J., Maciewicz, R.A., and Humphries, M.J. (2004). Integrin $\alpha 5 \beta 1$ and ADAM-17 interact in vitro and co-localize in migrating HeLa cells*. J. Biol. Chem. 279: 22377-22386.

Behnke, K., Zhuang, Y., Xu, H.C., Sundaram, B., Reich, M., Shinde, P.V., Huang, J., Modares, N.F., Tumanov, A.V., Polz, R., et al. (2018). B cell-mediated maintenance of cluster of differentiation 169-positive cells is critical for liver regeneration. Hepatology 68: 2348-2361.

Berasain, C., García-Trevijano, E.R., Castillo, J., Erroba, E., Lee, D.C., Prieto, J., and Avila, M.A. (2005a). Amphiregulin: an early trigger of liver regeneration in mice. Gastroenterology 128: 424-432.

Berasain, C., Garcia-Trevijano, E.R., Castillo, J., Erroba, E., Santamaria, M., Lee, D.C., Prieto, J., and Avila, M.A. (2005b). Novel role for amphiregulin in protection from liver injury. J. Biol. Chem. 280: 19012-19020.

Beyer, M., Abdullah, Z., Chemnitz, J.M., Maisel, D., Sander, J., Lehmann, C., Thabet, Y., Shinde, P.V., Schmidleithner, L., Kohne, M., et al. (2016). Tumor-necrosis factor impairs CD4 T cell-mediated immunological control in chronic viral infection. Nat. Immunol. 17: 593-603.

Black, R.A., Rauch, C.T., Kozlosky, C.J., Peschon, J.J., Slack, J.L., Wolfson, M.F., Castner, B.J., Stocking, K.L., Reddy, P., Srinivasan, S., et al. (1997). A metalloproteinase disintegrin that releases tumour-necrosis factor- $\alpha$ from cells. Nature 385 : 729-733.

Blaydon, D.C., Etheridge, S.L., Risk, J.M., Hennies, H.C., Gay, L.J., Carroll, R., Plagnol, V., McRonald, F.E., Stevens, H.P., Spurr, N.K., et al. (2012). RHBDF2 mutations are associated with tylosis, a familial esophageal cancer syndrome. Am. J. Hum. Genet. 90: 340-346.

Brooke, M.A., Etheridge, S.L., Kaplan, N., Simpson, C., O’Toole, E.A., Ishida-Yamamoto, A., Marches, O., Getsios, S., and Kelsell, D.P. (2014). iRHOM2-dependent regulation of ADAM17 in cutaneous disease and epidermal barrier function. Hum. Mol. Genet. 23: 4064-4076.

Buryova, H., Chalupsky, K., Zbodakova, O., Kanchev, I., Jirouskova, M., Gregor, M., and Sedlacek, R. (2013). Liver protective effect of ursodeoxycholic acid includes regulation of ADAM17 activity. BMC Gastroenterol. 13: 155.

Byass, P. (2014). The global burden of liver disease: a challenge for methods and for public health. BMC Med. 12: 159.

Cai, B., Dongiovanni, P., Corey, K.E., Wang, X., Shmarakov, I.O., Zheng, Z., Kasikara, C., Davra, V., Meroni, M., Chung, R.T., et al. (2020). Macrophage MerTK promotes liver fibrosis in nonalcoholic steatohepatitis. Cell Metabol. 31: 406-421.e7.

Cai, Z., Jitkaew, S., Zhao, J., Chiang, H.C., Choksi, S., Liu, J., Ward, Y., Wu, L.G., and Liu, Z.G. (2014). Plasma membrane translocation of trimerized MLKL protein is required for TNF-induced necroptosis. Nat. Cell Biol. 16: 55-65.

Calligaris, M., Cuffaro, D., Bonelli, S., Spanò, D.P., Rossello, A., Nuti, E., and Scilabra, S.D. (2021). Strategies to target ADAM17 in disease: from its discovery to the iRhom revolution. Molecules 26: 944.

Carswell, E.A., Old, L.J., Kassel, R.L., Green, S., Fiore, N., and Williamson, B. (1975). An endotoxin-induced serum factor that causes necrosis of tumors. Proc. Natl. Acad. Sci. U.S.A. 72: 3666.

Casagrande, V., Mauriello, A., Bischetti, S., Mavilio, M., Federici, M., and Menghini, R. (2017). Hepatocyte specific TIMP3 expression prevents diet dependent fatty liver disease and hepatocellular carcinoma. Sci. Rep. 7:6747.

Cavadas, M., Oikonomidi, I., Gaspar, C.J., Burbridge, E., Badenes, M., Felix, I., Bolado, A., Hu, T., Bileck, A., Gerner, C., et al. (2017). Phosphorylation of iRhom 2 controls stimulated proteolytic shedding by the metalloprotease ADAM17/TACE. Cell Rep. 21: 745-757.

Chalaris, A., Adam, N., Sina, C., Rosenstiel, P., Lehmann-Koch, J., Schirmacher, P., Hartmann, D., Cichy, J., Gavrilova, O., Schreiber, S., et al. (2010). Critical role of the disintegrin metalloprotease ADAM17 for intestinal inflammation and regeneration in mice. J. Exp. Med. 207: 1617-1624.

Chalupský, K., Kanchev, I., Žbodáková, O., Buryová, H., Jiroušková, M., Kořínek, V., Gregor, M., and Sedláček, R. (2013). ADAM10/ 17-dependent release of soluble c-Met correlates with hepatocellular damage. Folia Biol. 59: 76-86.

Cressman, D.E., Greenbaum, L.E., DeAngelis, R.A., Ciliberto, G., Furth, E.E., Poli, V., and Taub, R. (1996). Liver failure and defective hepatocyte regeneration in interleukin-6-deficient mice. Science 274: 1379.

Demetris, A.J., Lunz, J.G., 3rd, Specht, S., and Nozaki, I. (2006). Biliary wound healing, ductular reactions, and IL-6/gp130 signaling in the development of liver disease. World J. Gastroenterol. 12: 3512-3522.

Dostert, C., Grusdat, M., Letellier, E., and Brenner, D. (2019). The TNF family of ligands and receptors: communication modules in the immune system and beyond. Physiol. Rev. 99: 115-160.

Düsterhöft, S., Jung, S., Hung, C.-W., Tholey, A., Sönnichsen, F.D., Grötzinger, J., and Lorenzen, I. (2013). Membrane-proximal domain of a disintegrin and metalloprotease- 17 represents the putative molecular switch of its shedding activity operated by protein-disulfide isomerase. J. Am. Chem. Soc. 135: 5776-5781.

Düsterhöft, S., Höbel, K., Oldefest, M., Lokau, J., Waetzig, G.H., Chalaris, A., Garbers, C., Scheller, J., Rose-John, S., Lorenzen, I., et al. (2014). A disintegrin and metalloprotease 17 dynamic interaction sequence, the sweet tooth for the human interleukin 6 receptor. J. Biol. Chem. 289: 16336-16348.

Düsterhöft, S., Michalek, M., Kordowski, F., Oldefest, M., Sommer, A., Röseler, J., Reiss, K., Grötzinger, J., and Lorenzen, I. (2015). Extracellular juxtamembrane segment of ADAM17 interacts with membranes and is essential for its shedding activity. Biochemistry 54: 5791-5801.

Düsterhöft, S., Babendreyer, A., Giese, A.A., Flasshove, C., and Ludwig, A. (2019). Status update on iRhom and ADAM17: it's still complicated. Biochim. Biophys. Acta Mol. Cell Res. 1866: 1567-1583.

Endres, K., Anders, A., Kojro, E., Gilbert, S., Fahrenholz, F., and Postina, R. (2003). Tumor necrosis factor-alpha converting enzyme is processed by proprotein-convertases to its mature 
form which is degraded upon phorbol ester stimulation. Eur. J. Biochem. 270: 2386-2393.

Fan, H. and Derynck, R. (1999). Ectodomain shedding of TGF-alpha and other transmembrane proteins is induced by receptor tyrosine kinase activation and MAP kinase signaling cascades. EMBO J. 18: 6962-6972.

Fan, H., Turck, C.W., and Derynck, R. (2003). Characterization of growth factor-induced serine phosphorylation of tumor necrosis factor-alpha converting enzyme and of an alternatively translated polypeptide. J. Biol. Chem. 278: 18617-18627.

Fazel Modares, N., Polz, R., Haghighi, F., Lamertz, L., Behnke, K., Zhuang, Y., Kordes, C., Haussinger, D., Sorg, U.R., Pfeffer, K., et al. (2019). IL-6 trans-signaling controls liver regeneration after partial hepatectomy. Hepatology 70: 2075-2091.

Feoktistova, M., Geserick, P., Kellert, B., Dimitrova, D.P., Langlais, C., Hupe, M., Cain, K., MacFarlane, M., Hacker, G., and Leverkus, M. (2011). clAPs block Ripoptosome formation, a RIP1/caspase-8 containing intracellular cell death complex differentially regulated by cFLIP isoforms. Mol. Cell 43: 449-463.

Fuchs, B.C., Hoshida, Y., Fujii, T., Wei, L., Yamada, S., Lauwers, G.Y., McGinn, C.M., DePeralta, D.K., Chen, X., Kuroda, T., et al. (2014). Epidermal growth factor receptor inhibition attenuates liver fibrosis and development of hepatocellular carcinoma. Hepatology 59: 1577-1590.

Fulda, S. (2015). Targeting extrinsic apoptosis in cancer: challenges and opportunities. Semin. Cell Dev. Biol. 39: 20-25.

Galluzzi, L., Kepp, O., and Kroemer, G. (2014). MLKL regulates necrotic plasma membrane permeabilization. Cell Res. 24: 139-140.

Galun, E., Zeira, E., Pappo, O., Peters, M., and Rose-John, S. (2000). Liver regeneration induced by a designer human IL-6/sIL-6R fusion protein reverses severe hepatocellular injury. Faseb. J. 14: 1979-1987.

Gandhi, C.R. (2017). Hepatic stellate cell activation and pro-fibrogenic signals. J. Hepatol. 67: 1104-1105.

Ge, C.X., Qin, Y.T., Lou, D.S., Li, Q., Li, Y.Y., Wang, Z.M., Yang, W.W., Wang, M., Liu, N., Wang, Z., et al. (2017). iRhom2 deficiency relieves TNF- $\alpha$ associated hepatic dyslipidemia in long-term PM2.5-exposed mice. Biochem. Biophys. Res. Commun. 493: 1402-1409.

Gechtman, Z., Alonso, J.L., Raab, G., Ingber, D.E., and Klagsbrun, M. (1999). The shedding of membrane-anchored heparin-binding epidermal-like growth factor is regulated by the Raf/mitogenactivated protein kinase cascade and by cell adhesion and spreading. J. Biol. Chem. 274: 28828-28835.

Gewiese-Rabsch, J., Drucker, C., Malchow, S., Scheller, J., and RoseJohn, S. (2010). Role of IL- 6 trans-signaling in CCl4 induced liver damage. Biochim. Biophys. Acta (BBA) - Mol. Basis Dis. 1802: 1054-1061.

Giebeler, A., Boekschoten, M.V., Klein, C., Borowiak, M., Birchmeier, C., Gassler, N., Wasmuth, H.E., Muller, M., Trautwein, C., and Streetz, K.L. (2009). c-Met confers protection against chronic liver tissue damage and fibrosis progression after bile duct ligation in mice. Gastroenterology 137: 297-308, 308 e1-4.

Golks, A., Brenner, D., Fritsch, C., Krammer, P.H., and Lavrik, I.N. (2005). c-FLIPR, a new regulator of death receptor-induced apoptosis. J. Biol. Chem. 280: 14507-14513.

Green S Fau-Chiasson, M.A., Chiasson Ma Fau-Shah, R.G., and Shah, R.G. Evidence for the presence of an antitumor factor in serum of normal animals (0304-3835 (Print)).
Grieve, A.G., Xu, H., Künzel, U., Bambrough, P., Sieber, B., and Freeman, M. (2017). Phosphorylation of iRhom 2 at the plasma membrane controls mammalian TACE-dependent inflammatory and growth factor signalling. eLife 6: e23968.

Grötzinger, J., Lorenzen, I., and Düsterhöft, S. (2017). Molecular insights into the multilayered regulation of ADAM17: the role of the extracellular region. Biochim. Biophys. Acta Mol. Cell Res. 1864: 2088-2095.

Guo, Y., Ding, Q., Chen, L., Ji, C., Hao, H., Wang, J., Qi, W., Xie, X., Ma, J., $\mathrm{Li}$, A., et al. (2017). Overexpression of heparin-binding epidermal growth factor-like growth factor mediates liver fibrosis in transgenic mice. Am. J. Med. Sci. 354: 199-210.

Heymann, F. and Tacke, F. (2016). Immunology in the liver-from homeostasis to disease. Nat. Rev. Gastroenterol. Hepatol. 13: 88-110.

Holler, N., Zaru, R., Micheau, O., Thome, M., Attinger, A., Valitutti, S., Bodmer, J.-L., Schneider, P., Seed, B., and Tschopp, J. (2000). Fas triggers an alternative, caspase-8-independent cell death pathway using the kinase RIP as effector molecule. Nat. Immunol. 1: 489-495.

Horiuchi, K., Kimura, T., Miyamoto, T., Takaishi, H., Okada, Y., Toyama, Y., and Blobel, C.P. (2007a). Cutting edge: TNF-alpha-converting enzyme (TACE/ADAM17) inactivation in mouse myeloid cells prevents lethality from endotoxin shock. J. Immunol. 179: 2686-2689.

Horiuchi, K., Le Gall, S., Schulte, M., Yamaguchi, T., Reiss, K., Murphy, G., Toyama, Y., Hartmann, D., Saftig, P., and Blobel, C.P. (2007b). Substrate selectivity of epidermal growth factor-receptor ligand sheddases and their regulation by phorbol esters and calcium influx. Mol. Biol. Cell 18: 176-188.

Hosur, V., Johnson, K.R., Burzenski, L.M., Stearns, T.M., Maser, R.S., and Shultz, L.D. (2014). Rhbdf2 mutations increase its protein stability and drive EGFR hyperactivation through enhanced secretion of amphiregulin. Proc. Natl. Acad. Sci. U.S.A. 111: E2200-E2209.

Hsu, H., Huang, J., Shu, H.-B., Baichwal, V., and Goeddel, D.V. (1996). TNF-dependent recruitment of the protein kinase RIP to the TNF receptor-1 signaling complex. Immunity 4: 387-396.

Hsu, H., Xiong, J., and Goeddel, D.V. (1995). The TNF receptor 1-associated protein TRADD signals cell death and NF-KB activation. Cell 81: 495-504.

Huang, J., Bridges, L.C., and White, J.M. (2005). Selective modulation of integrin-mediated cell migration by distinct ADAM family members. Mol. Biol. Cell 16: 4982-4991.

Irmler, M., Thome, M., Hahne, M., Schneider, P., Hofmann, K., Steiner, V., Bodmer, J.-L., Schröter, M., Burns, K., Mattmann, C., et al. (1997). Inhibition of death receptor signals by cellular FLIP. Nature 388: 190-195.

Ishizaki, K., Iwaki, T., Kinoshita, S., Koyama, M., Fukunari, A., Tanaka, H., Tsurufuji, M., Sakata, K., Maeda, Y., Imada, T., et al. (2008). Ursodeoxycholic acid protects concanavalin A-induced mouse liver injury through inhibition of intrahepatic tumor necrosis factor-alpha and macrophage inflammatory protein-2 production. Eur. J. Pharmacol. 578: 57-64.

Iwaisako, K., Jiang, C., Zhang, M., Cong, M., Moore-Morris, T.J., Park, T.J., Liu, X., Xu, J., Wang, P., Paik, Y.H., et al. (2014). Origin of myofibroblasts in the fibrotic liver in mice. Proc. Natl. Acad. Sci. U.S.A. 111: E3297-E3305.

Jedicke, N., Struever, N., Aggrawal, N., Welte, T., Manns, M.P., Malek, N.P., Zender, L., Janciauskiene, S., and Wuestefeld, T. (2014). $\alpha$ - 
1-antitrypsin inhibits acute liver failure in mice. Hepatology 59: 2299-2308.

Jia, B., Guo, M., Li, G., Yu, D., Zhang, X., Lan, K., and Deng, Q. (2015). Hepatitis B virus core protein sensitizes hepatocytes to tumor necrosis factor-induced apoptosis by suppression of the phosphorylation of mitogen-activated protein kinase kinase 7 . J. Virol. 89: 2041-2051.

Jin, X., Zimmers, T.A., Perez, E.A., Pierce, R.H., Zhang, Z., and Koniaris, L.G. (2006). Paradoxical effects of short- and long-term interleukin-6 exposure on liver injury and repair. Hepatology 43: 474-484.

Kaldenbach, M., Giebeler, A., Tschaharganeh, D.F., Erschfeld, S., Wasmuth, H.E., Dolle, L., Floege, J., Trautwein, C., and Streetz, K.L. (2012). Hepatocyte growth factor/c-Met signalling is important for the selection of transplanted hepatocytes. Gut 61: 1209-1218.

Kasahara, S., Ando, K., Saito, K., Sekikawa, K., Ito, H., Ishikawa, T., Ohnishi, H., Seishima, M., Kakumu, S., and Moriwaki, H. (2003). Lack of tumor necrosis factor $\alpha$ induces impaired proliferation of hepatitis B virus-specific cytotoxic T lymphocytes. J. Virol. 77: 2469-2476.

Killock, D.J. and Ivetic, A. (2010). The cytoplasmic domains of TNFalpha-converting enzyme (TACE/ADAM17) and L-selectin are regulated differently by $\mathrm{p} 38$ MAPK and PKC to promote ectodomain shedding. Biochem. J. 428: 293-304.

Kiso, S., Kawata, S., Tamura, S., Inui, Y., Yoshida, Y., Sawai, Y., Umeki, S., Ito, N., Yamada, A., Miyagawa, J., et al. (2003). Liver regeneration in heparin-binding EGF-like growth factor transgenic mice after partial hepatectomy. Gastroenterology 124: 701-707.

Kondylis, V. and Pasparakis, M. (2019). RIP kinases in liver cell death, inflammation and cancer. Trends Mol. Med. 25: 47-63.

Kornfeld, J.W., Meder, S., Wohlberg, M., Friedrich, R.E., Rau, T., Riethdorf, L., Loning, T., Pantel, K., and Riethdorf, S. (2011). Overexpression of TACE and TIMP3 mRNA in head and neck cancer: association with tumour development and progression. Br. J. Canc. 104: 138-145.

Koyama, Y. and Brenner, D.A. (2017). Liver inflammation and fibrosis. J. Clin. Invest. 127: 55-64.

Kriegler, M., Perez, C., DeFay, K., Albert, I., and Lu, S.D. (1988). A novel form of TNF/cachectin is a cell surface cytotoxic transmembrane protein: ramifications for the complex physiology of TNF. Cell 53: 45-53.

Kroy, D.C., Beraza, N., Tschaharganeh, D.F., Sander, L.E., Erschfeld, S., Giebeler, A., Liedtke, C., Wasmuth, H.E., Trautwein, C., and Streetz, K.L. (2010). Lack of interleukin-6/glycoprotein 130/signal transducers and activators of transcription-3 signaling in hepatocytes predisposes to liver steatosis and injury in mice. Hepatology 51: 463-473.

Lambrecht, B.N., Vanderkerken, M., and Hammad, H. (2018). The emerging role of ADAM metalloproteinases in immunity. Nat. Rev. Immunol. 18: 745-758.

Lanaya, H., Natarajan, A., Komposch, K., Li, L., Amberg, N., Chen, L., Wculek, S.K., Hammer, M., Zenz, R., Peck-Radosavljevic, M., et al. (2014). EGFR has a tumour-promoting role in liver macrophages during hepatocellular carcinoma formation. Nat. Cell Biol. 16: 1-7.

Le Gall, S.M., Maretzky, T., Issuree, P.D., Niu, X.D., Reiss, K., Saftig, P., Khokha, R., Lundell, D., and Blobel, C.P. (2010). ADAM17 is regulated by a rapid and reversible mechanism that controls access to its catalytic site. J. Cell Sci. 123: 3913-3922.
Lee, J.R., Urban, S., Garvey, C.F., and Freeman, M. (2001). Regulated intracellular ligand transport and proteolysis control EGF signal activation in Drosophila. Cell 107: 161-171.

Lemberg, M.K. and Freeman, M. (2007). Functional and evolutionary implications of enhanced genomic analysis of rhomboid intramembrane proteases. Genome Res. 17: 1634-1646.

Lemjabbar-Alaoui, H., Sidhu, S.S., Mengistab, A., Gallup, M., and Basbaum, C. (2011). TACE/ADAM-17 phosphorylation by PKC-epsilon mediates premalignant changes in tobacco smokeexposed lung cells. PloS One 6: e17489.

Li, X., Maretzky, T., Weskamp, G., Monette, S., Qing, X., Issuree, P.D., Crawford, H.C., Mcllwain, D.R., Mak, T.W., Salmon, J.E., et al. (2015). iRhoms 1 and 2 are essential upstream regulators of ADAM17-dependent EGFR signaling. Proc. Natl. Acad. Sci. U.S.A. 112: 6080-6085.

Liccardi, G., Ramos Garcia, L., Tenev, T., Annibaldi, A., Legrand, A.J., Robertson, D., Feltham, R., Anderton, H., Darding, M., Peltzer, N., et al. (2019). RIPK1 and caspase-8 ensure chromosome stability independently of their role in cell death and inflammation. Mol. Cell 73: 413-428 e7.

Lorenzen, I., Lokau, J., Düsterhöft, S., Trad, A., Garbers, C., Scheller, J., Rose-John, S., and Grötzinger, J. (2012). The membraneproximal domain of A disintegrin and metalloprotease 17 (ADAM17) is responsible for recognition of the interleukin-6 receptor and interleukin-1 receptor II. FEBS Lett. 586: 1093-1100.

Luedde, T., Kaplowitz, N., and Schwabe, R.F. (2014). Cell death and cell death responses in liver disease: mechanisms and clinical relevance. Gastroenterology 147: 765-U110.

Mackiewicz, A., Schooltink, H., Heinrich, P.C., and Rose-John, S. (1992). Complex of soluble human IL-6-receptor/IL-6 upregulates expression of acute-phase proteins. J. Immunol. 149: 2021-2027.

Maney, S.K., Mcllwain, D.R., Polz, R., Pandyra, A.A., Sundaram, B., Wolff, D., Ohishi, K., Maretzky, T., Brooke, M.A., Evers, A., et al. (2015). Deletions in the cytoplasmic domain of iRhom 1 and iRhom 2 promote shedding of the TNF receptor by the protease ADAM17. Sci. Signal. 8: ra109.

Maretzky, T., Mcllwain, D.R., Issuree, P.D., Li, X., Malapeira, J., Amin, S., Lang, P.A., Mak, T.W., and Blobel, C.P. (2013). iRhom2 controls the substrate selectivity of stimulated ADAM17-dependent ectodomain shedding. Proc. Natl. Acad. Sci. U.S.A. 110: 11433-11438.

Maskos, K., Fernandez-Catalan, C., Huber, R., Bourenkov, G.P., Bartunik, H., Ellestad, G.A., Reddy, P., Wolfson, M.F., Rauch, C.T., Castner, B.J., et al. (1998). Crystal structure of the catalytic domain of human tumor necrosis factor- $\alpha$-converting enzyme. Proc. Natl. Acad. Sci. U.S.A. 95: 3408-3412.

Mcllwain, D.R., Lang, P.A., Maretzky, T., Hamada, K., Ohishi, K., Maney, S.K., Berger, T., Murthy, A., Duncan, G., Xu, H.C., et al. (2012). iRhom 2 regulation of TACE controls TNF-mediated protection against Listeria and responses to LPS. Science 335: 229-232.

McKee, C., Sigala, B., Soeda, J., Mouralidarane, A., Morgan, M., Mazzoccoli, G., Rappa, F., Cappello, F., Cabibi, D., Pazienza, V., et al. (2015). Amphiregulin activates human hepatic stellate cells and is upregulated in non alcoholic steatohepatitis. Sci. Rep. 5: 8812.

McMahan, R.S., Riehle, K.J., Fausto, N., and Campbell, J.S. (2013). A disintegrin and metalloproteinase 17 regulates TNF and TNFR1 
levels in inflammation and liver regeneration in mice. Am. J. Physiol. Gastrointest. Liver Physiol. 305: G25-G34.

Michalopoulos, G.K. (2007). Liver regeneration. J. Cell. Physiol. 213: 286-300.

Milla, M.E., Leesnitzer, M.A., Moss, M.L., Clay, W.C., Carter, H.L., Miller, A.B., Su, J.-L., Lambert, M.H., Willard, D.H., Sheeley, D.M., et al. (1999). Specific sequence elements are required for the expression of functional tumor necrosis factor- $\alpha$-converting enzyme (TACE). J. Biol. Chem. 274: 30563-30570.

Mitchell, C., Nivison, M., Jackson, L.F., Fox, R., Lee, D.C., Campbell, J.S., and Fausto, N. (2005). Heparin-binding epidermal growth factorlike growth factor links hepatocyte priming with cell cycle progression during liver regeneration. J. Biol. Chem. 280: 2562-2568.

Mohler, K.M., Sleath, P.R., Fitzner, J.N., Cerretti, D.P., Alderson, M., Kerwar, S.S., Torrance, D.S., Otten-Evans, C., Greenstreet, T., Weerawarna, K., et al. (1994). Protection against a lethal dose of endotoxin by an inhibitor of tumour necrosis factor processing. Nature 370: 218-220.

Moss, M.L., Jin, S.L.C., Milla, M.E., Burkhart, W., Carter, H.L., Chen, W.-J., Clay, W.C., Didsbury, J.R., Hassler, D., Hoffman, C.R., et al. (1997). Cloning of a disintegrin metalloproteinase that processes precursor tumour-necrosis factor- $\alpha$. Nature 385: 733-736.

Moss, M.L., Sklair-Tavron, L., and Nudelman, R. (2008). Drug Insight: tumor necrosis factor-converting enzyme as a pharmaceutical target for rheumatoid arthritis. Nat. Clin. Pract. Rheumatol. 4: 300-309.

Müllberg, J., Schooltink, H., Stoyan, T., Günther, M., Graeve, L., Buse, G., Mackiewicz, A., Heinrich, P.C., and Rose-John, S. (1993). The soluble interleukin- 6 receptor is generated by shedding. Eur. J. Immunol. 23: 473-480.

Murthy, A., Defamie, V., Smookler, D.S., Di Grappa, M.A., Horiuchi, K., Federici, M., Sibilia, M., Blobel, C.P., and Khokha, R. (2010). Ectodomain shedding of EGFR ligands and TNFR1 dictates hepatocyte apoptosis during fulminant hepatitis in mice. J. Clin. Invest. 120: 2731-2744.

Nagano, O., Murakami, D., Hartmann, D., De Strooper, B., Saftig, P., Iwatsubo, T., Nakajima, M., Shinohara, M., and Saya, H. (2004). Cell-matrix interaction via CD44 is independently regulated by different metalloproteinases activated in response to extracellular $\mathrm{Ca}(2+)$ influx and PKC activation. J. Cell Biol. 165: 893-902.

Natarajan, A., Wagner, B., and Sibilia, M. (2007). The EGF receptor is required for efficient liver regeneration. Proc. Natl. Acad. Sci. U. S. A. 104: 17081-17086.

Neuman, M., Angulo, P., Malkiewicz, I., Jorgensen, R., Shear, N., Dickson, E.R., Haber, J., Katz, G., and Lindor, K. (2002). Tumor necrosis factor- $\alpha$ and transforming growth factor-beta reflect severity of liver damage in primary biliary cirrhosis.

J. Gastroenterol. Hepatol. 17: 196-202.

Nozaki, I., Lunz, J.G., 3rd, Specht, S., Stolz, D.B., Taguchi, K., Subbotin, V.M., Murase, N., and Demetris, A.J. (2005). Small proline-rich proteins 2 are noncoordinately upregulated by IL-6/ STAT3 signaling after bile duct ligation. Lab. Invest. 85: 109-123.

Osawa, Y., Hoshi, M., Yasuda, I., Saibara, T., Moriwaki, H., and Kozawa, O. (2013). Tumor necrosis factor-alpha promotes cholestasis-induced liver fibrosis in the mouse through tissue inhibitor of metalloproteinase-1 production in hepatic stellate cells. PloS One 8: e65251.
Park, J., Kang, W., Ryu, S.W., Kim, W.I., Chang, D.Y., Lee, D.H., Park do, Y., Choi, Y.H., Choi, K., Shin, E.C., et al. (2012). Hepatitis C virus infection enhances TNFalpha-induced cell death via suppression of NF-kappaB. Hepatology 56: 831-840.

Peschon, J.J., Slack, J.L., Reddy, P., Stocking, K.L., Sunnarborg, S.W., Lee, D.C., Russell, W.E., Castner, B.J., Johnson, R.S., Fitzner, J.N., et al. (1998). An essential role for ectodomain shedding in mammalian development. Science 282: 1281-1284.

Peters, M., Blinn, G., Jostock, T., Schirmacher, P., Zum Buschenfelde, K.H.M., Galle, P.R., and Rose-John, S. (2000). Combined interleukin 6 and soluble interleukin 6 receptor accelerates murine liver regeneration. Gastroenterology 119: 1663-1671.

Pfeffer, K., Matsuyama, T., Kundig, T.M., Wakeham, A., Kishihara, K., Shahinian, A., Wiegmann, K., Ohashi, P.S., Kronke, M., and Mak, T.W. (1993). Mice deficient for the $55 \mathrm{kd}$ tumor necrosis factor receptor are resistant to endotoxic shock, yet succumb to $L$. monocytogenes infection. Cell 73: 457-467.

Pop, C., Oberst, A., Drag, M., Van Raam, B.J., Riedl, S.J., Green, D.R., and Salvesen, G.S. (2011). FLIP(L) induces caspase 8 activity in the absence of interdomain caspase 8 cleavage and alters substrate specificity. Biochem. J. 433: 447-457.

Pradere, J.P., Kluwe, J., De Minicis, S., Jiao, J.J., Gwak, G.Y., Dapito, D.H., Jang, M.K., Guenther, N.D., Mederacke, I., Friedman, R., et al. (2013). Hepatic macrophages but not dendritic cells contribute to liver fibrosis by promoting the survival of activated hepatic stellate cells in mice. Hepatology 58: 1461-1473.

Reddy, P., Slack, J.L., Davis, R., Cerretti, D.P., Kozlosky, C.J., Blanton, R.A., Shows, D., Peschon, J.J., and Black, R.A. (2000). Functional analysis of the domain structure of tumor necrosis factor-alpha converting enzyme. J. Biol. Chem. 275: 14608-14614.

Riethmueller, S., Ehlers, J.C., Lokau, J., Düsterhöft, S., Knittler, K., Dombrowsky, G., Grötzinger, J., Rabe, B., Rose-John, S., and Garbers, C. (2016). Cleavage site localization differentially controls interleukin- 6 receptor proteolysis by ADAM10 and ADAM17. Sci. Rep. 6: 25550.

Riethmueller, S., Somasundaram, P., Ehlers, J.C., Hung, C.W., Flynn, C.M., Lokau, J., Agthe, M., Düsterhöft, S., Zhu, Y., Grötzinger, J., et al. (2017). Proteolytic origin of the soluble human IL-6R in vivo and a decisive role of N-glycosylation. PLoS Biol. 15: e2000080.

Ringel, J., Jesnowski, R., Moniaux, N., Luttges, J., Ringel, J., Choudhury, A., Batra, S.K., Kloppel, G., and Lohr, M. (2006). Aberrant expression of a disintegrin and metalloproteinase $17 /$ tumor necrosis factor-alpha converting enzyme increases the malignant potential in human pancreatic ductal adenocarcinoma. Canc. Res. 66: 9045-9053.

Robinson, M.W., Harmon, C., and O'Farrelly, C. (2016). Liver immunology and its role in inflammation and homeostasis. Cell. Mol. Immunol. 13: 267-276.

Rossello, A., Nuti, E., Ferrini, S., and Fabbi, M. (2016). Targeting ADAM17 sheddase activity in cancer. Curr. Drug Targets 17: 1908-1927.

Rothe, J., Lesslauer, W., Lotscher, H., Lang, Y., Koebel, P., Kontgen, F., Althage, A., Zinkernagel, R., Steinmetz, M., and Bluethmann, H. (1993). Mice lacking the tumour necrosis factor receptor 1 are resistant to TNF-mediated toxicity but highly susceptible to infection by Listeria monocytogenes. Nature 364: 798-802.

Rzymski, T., Petry, A., Kracun, D., Riess, F., Pike, L., Harris, A.L., and Gorlach, A. (2012). The unfolded protein response controls induction and activation of ADAM17/TACE by severe hypoxia and ER stress. Oncogene 31: 3621-3634. 
Saad, M.I., Alhayyani, S., McLeod, L., Yu, L., Alanazi, M., Deswaerte, V., Tang, K., Jarde, T., Smith, J.A., Prodanovic, Z., et al. (2019). ADAM17 selectively activates the IL- 6 trans-signaling/ERK MAPK axis in KRAS-addicted lung cancer. EMBO Mol. Med. 11: e9976.

Saarinen, S., Vahteristo, P., Lehtonen, R., Aittomaki, K., Launonen, V., Kiviluoto, T., and Aaltonen, L.A. (2012). Analysis of a Finnish family confirms RHBDF2 mutations as the underlying factor in tylosis with esophageal cancer. Fam. Cancer 11: 525-528.

Sahin, U. and Blobel, C.P. (2007). Ectodomain shedding of the EGF-receptor ligand epigen is mediated by ADAM17. FEBS Lett. 581: 41-44.

Sahin, U., Weskamp, G., Kelly, K., Zhou, H.M., Higashiyama, S., Peschon, J., Hartmann, D., Saftig, P., and Blobel, C.P. (2004). Distinct roles for ADAM10 and ADAM17 in ectodomain shedding of six EGFR ligands. J. Cell Biol. 164: 769-779.

Santamaria, E., Rodriguez-Ortigosa, C.M., Uriarte, I., Latasa, M.U., Urtasun, R., Alvarez-Sola, G., Barcena-Varela, M., Colyn, L., Arcelus, S., Jimenez, M., et al. (2019). The epidermal growth factor receptor ligand amphiregulin protects from cholestatic liver injury and regulates bile acids synthesis. Hepatology 69: 1632-1647.

Satoh, H., Nakamura, M., Satoh, M., Nakajima, T., Izumoto, H., Maesawa, C., Kawazoe, K., Masuda, T., and Hiramori, K. (2004). Expression and localization of tumour necrosis factor-alpha and its converting enzyme in human abdominal aortic aneurysm. Clin. Sci. 106: 301-306.

Satoh, M., Ishikawa, Y., Itoh, T., Minami, Y., Takahashi, Y., and Nakamura, M. (2008). The expression of TNF-alpha converting enzyme at the site of ruptured plaques in patients with acute myocardial infarction. Eur. J. Clin. Invest. 38: 97-105.

Schlondorff, J., Becherer, J.D., and Blobel, C.P. (2000). Intracellular maturation and localization of the tumour necrosis factor alpha convertase (TACE). Biochem. J. 347: 131-138.

Schmidt-Arras, D. and Rose-John, S. (2016). IL-6 pathway in the liver: from physiopathology to therapy. J. Hepatol. 64: 1403-1415.

Schütze, S., Hartmann, D., Matthews, V., Schuster, B., Bussmeyer, I., Ludwig, A., Hundhausen, C., Sadowski, T., Saftig, P., Kallen, K.-J., et al. (2003). Cellular cholesterol depletion triggers shedding of the human interleukin- 6 receptor by ADAM10 and ADAM17 (TACE). J. Biol. Chem. 278: 38829-38839.

Schwabe, R.F. and Brenner, D.A. (2006). Mechanisms of liver injury. I. TNF-alpha-induced liver injury: role of IKK, JNK, and ROS pathways. Am. J. Physiol. Gastrointest. Liver Physiol. 290: G583-G589.

Schwarz, J., Schmidt, S., Will, O., Koudelka, T., Kohler, K., Boss, M., Rabe, B., Tholey, A., Scheller, J., Schmidt-Arras, D., et al. (2014). Polo-like kinase 2, a novel ADAM17 signaling component, regulates tumor necrosis factor alpha ectodomain shedding. J. Biol. Chem. 289: 3080-3093.

Seki, E., De Minicis, S., Osterreicher, C.H., Kluwe, J., Osawa, Y., Brenner, D.A., and Schwabe, R.F. (2007). TLR4 enhances TGF-beta signaling and hepatic fibrosis. Nat. Med. 13: 1324-1332.

Siggs, O.M., Grieve, A., Xu, H., Bambrough, P., Christova, Y., and Freeman, $M$. (2014). Genetic interaction implicates iRhom 2 in the regulation of EGF receptor signalling in mice. Biol. Open 3: 1151-1157.

Siggs, O.M., Xiao, N., Wang, Y., Shi, H., Tomisato, W., Li, X., Xia, Y., and Beutler, B. (2012). iRhom2 is required for the secretion of mouse TNFalpha. Blood 119: 5769-5771.
Sigismund, S., Avanzato, D., and Lanzetti, L. (2018). Emerging functions of the EGFR in cancer. Mol. Oncol. 12: 3-20.

Sommer, A., Bhakdi, S., and Reiss, K. (2016a). How membrane asymmetry regulates ADAM17 sheddase function. Cell Cycle 15: 2995-2996.

Sommer, A., Kordowski, F., Büch, J., Maretzky, T., Evers, A., Andrä, J., Düsterhöft, S., Michalek, M., Lorenzen, I., Somasundaram, P., et al. (2016b). Phosphatidylserine exposure is required for ADAM17 sheddase function. Nat. Commun. 7: 11523.

Soond, S.M., Everson, B., Riches, D.W., and Murphy, G. (2005). ERK-mediated phosphorylation of Thr735 in TNFalpha-converting enzyme and its potential role in TACE protein trafficking. J. Cell Sci. 118: 2371-2380.

Soung, Y.H., Lee, J.W., Kim, S.Y., Sung, Y.J., Park, W.S., Nam, S.W., Kim, S.H., Lee, J.Y., Yoo, N.J., and Lee, S.H. (2005). Caspase-8 gene is frequently inactivated by the frameshift somatic mutation 1225_1226delTG in hepatocellular carcinomas. Oncogene 24: 141-147.

Stennicke, H.R., Jürgensmeier, J.M., Shin, H., Deveraux, Q., Wolf, B.B., Yang, X., Zhou, Q., Ellerby, H.M., Ellerby, L.M., Bredesen, D., et al. (1998). Pro-caspase-3 is a major physiologic target of caspase-8. J. Biol. Chem. 273: 27084-27090.

Sundaram, B., Behnke, K., Belancic, A., Al-Salihi, M.A., Thabet, Y., Polz, R., Pellegrino, R., Zhuang, Y., Shinde, P.V., Xu, H.C., et al. (2019). iRhom 2 inhibits bile duct obstruction-induced liver fibrosis. Sci. Signal. 12: eaax1194.

Suresh, M., Singh, A., and Fischer, C. (2005). Role of tumor necrosis factor receptors in regulating CD8 T-cell responses during acute lymphocytic choriomeningitis virus infection. J. Virol. 79: 202-213.

Takeda, S. (2009). Three-dimensional domain architecture of the ADAM family proteinases. Semin. Cell Dev. Biol. 20: 146-152.

Takeda, S., Igarashi, T., Mori, H., and Araki, S. (2006). Crystal structures of VAP1 reveal ADAMs' MDC domain architecture and its unique C-shaped scaffold. EMBO J. 25: 2388-2396.

Takemura, T., Yoshida, Y., Kiso, S., Saji, Y., Ezaki, H., Hamano, M., Kizu, T., Egawa, M., Chatani, N., Furuta, K., et al. (2013). Conditional knockout of heparin-binding epidermal growth factor-like growth factor in the liver accelerates carbon tetrachloride-induced liver injury in mice. Hepatol. Res. 43: 384-393.

Tanaka, T., Narazaki, M., and Kishimoto, T. (2014). IL-6 in inflammation, immunity, and disease. Cold Spring Harb. Perspect. Biol. 6: a016295.

Tarrats, N., Moles, A., Morales, A., Garcia-Ruiz, C., Fernandez-Checa, J.C., and Mari, M. (2011). Critical role of tumor necrosis factor receptor 1 , but not 2, in hepatic stellate cell proliferation, extracellular matrix remodeling, and liver fibrogenesis. Hepatology 54: 319-327.

Tellier, E., Canault, M., Rebsomen, L., Bonardo, B., Juhan-Vague, I., Nalbone, G., and Peiretti, F. (2006). The shedding activity of ADAM17 is sequestered in lipid rafts. Exp. Cell Res. 312: 3969-3980.

Ting, A.T., Pimentel-Muiños, F.X., and Seed, B. (1996). RIP mediates tumor necrosis factor receptor 1 activation of NF-kappaB but not Fas/APO-1-initiated apoptosis. EMBO J. 15: 6189-6196.

Trautwein, C., Rakemann, T., Niehof, M., Rose-John, S., and Manns, M.P. (1996). Acute-phase response factor, increased binding, and target gene transcription during liver regeneration. Gastroenterology 110: 1854-1862. 
Urban, S., Lee, J.R., and Freeman, M. (2001). Drosophila rhomboid-1 defines a family of putative intramembrane serine proteases. Cell 107: 173-182.

Vercammen, D., Beyaert, R., Denecker, G., Goossens, V., Van Loo, G., Declercq, W., Grooten, J., Fiers, W., and Vandenabeele, P. (1998). Inhibition of caspases increases the sensitivity of $L 929$ cells to necrosis mediated by tumor necrosis factor. J. Exp. Med. 187: 1477-1485.

Walsh, M.J., Vanags, D.M., Clouston, A.D., Richardson, M.M., Purdie, D.M., Jonsson, J.R., and Powell, E.E. (2004). Steatosis and liver cell apoptosis in chronic hepatitis C: a mechanism for increased liver injury. Hepatology 39: 1230-1238.

Wang, L., Du, F., and Wang, X. (2008). TNF-alpha induces two distinct caspase-8 activation pathways. Cell 133: 693-703.

Wang, H., Sun, L., Su, L., Rizo, J., Liu, L., Wang, L.-F., Wang, F.-S., and Wang, X. (2014). Mixed lineage kinase domain-like protein MLKL causes necrotic membrane disruption upon phosphorylation by RIP3. Mol. Cell 54: 133-146.

Weber, K., Roelandt, R., Bruggeman, I., Estornes, Y., and Vandenabeele, P. (2018). Nuclear RIPK3 and MLKL contribute to cytosolic necrosome formation and necroptosis. Commun. Biol. 1: 6 .

Wetzel, S., Seipold, L., and Saftig, P. (2017). The metalloproteinase ADAM10: a useful therapeutic target? Biochim. Biophys. Acta Mol. Cell Res. 1864: 2071-2081.

Wisniewska, M., Goettig, P., Maskos, K., Belouski, E., Winters, D., Hecht, R., Black, R., and Bode, W. (2008). Structural determinants of the ADAM inhibition by TIMP-3: crystal structure of the TACE-N-TIMP-3 complex. J. Mol. Biol. 381: 1307-1319.

Wong, E., Cohen, T., Romi, E., Levin, M., Peleg, Y., Arad, U., Yaron, A., Milla, M.E., and Sagi, I. (2016). Harnessing the natural inhibitory domain to control TNF $\alpha$ converting enzyme (TACE) activity in vivo. Sci. Rep. 6: 35598.

Wong, E., Maretzky, T., Peleg, Y., Blobel, C.P., and Sagi, I. (2015). The functional maturation of $A$ disintegrin and metalloproteinase (ADAM) 9, 10, and 17 requires processing at a newly identified proprotein convertase (PC) cleavage site. J. Biol. Chem. 290: 12135-12146.

Wuestefeld, T., Klein, C., Streetz, K.L., Beraza, N., Scholmerich, J., Burgart, L.J., Zender, L., Kubicka, S., Baskin-Bey, E., Gores, G.J., et al. (2005). Lack of gp130 expression results in more bacterial infection and higher mortality during chronic cholestasis in mice. Hepatology 42: 1082-1090.

Xie, L., Jiang, F., Zhang, X., Alitongbieke, G., Shi, X., Meng, M., Xu, Y., Ren, A., Wang, J., Cai, L., et al. (2016). Honokiol sensitizes breast cancer cells to TNF- $\alpha$ induction of apoptosis by inhibiting Nur77 expression. Br. J. Pharmacol. 173: 344-356.
Xu, P. and Derynck, R. (2010). Direct activation of TACE-mediated ectodomain shedding by $\mathrm{p} 38 \mathrm{MAP}$ kinase regulates EGF receptordependent cell proliferation. Mol. Cell 37: 551-566.

Xu, H., Li, H., Cao, D., Wu, Y., and Chen, Y. (2014). Tumor necrosis factor alpha (TNF-alpha) receptor-I is required for TNF-alphamediated fulminant virus hepatitis caused by murine hepatitis virus strain-3 infection. Immunol. Lett. 158: 25-32.

Xu, M., Ge, C., Zhu, L., Qin, Y., Du, C., Lou, D., Li, Q., Hu, L., Sun, Y., Dai, X., et al. (2020). iRhom 2 promotes hepatic steatosis by activating MAP3K7-dependent pathway. Hepatology 73: 1346-1364.

Yamaguchi, K., Itoh, Y., Yokomizo, C., Nishimura, T., Niimi, T., Umemura, A., Fujii, H., Okanoue, T., and Yoshikawa, T. (2011). Blockade of IL- 6 signaling exacerbates liver injury and suppresses antiapoptotic gene expression in methionine choline-deficient diet-Fed db/db mice. Lab. Invest. 91: 609-618.

Yin, M., Wheeler, M.D., Kono, H., Bradford, B.U., Gallucci, R.M., Luster, M.I., and Thurman, R.G. (1999). Essential role of tumor necrosis factor alpha in alcohol-induced liver injury in mice. Gastroenterology 117: 942-952.

Yoda, M., Kimura, T., Tohmonda, T., Morioka, H., Matsumoto, M., Okada, Y., Toyama, Y., and Horiuchi, K. (2013). Systemic overexpression of TNF $\alpha$-converting enzyme does not lead to enhanced shedding activity in vivo. PloS One 8: e54412.

Yu, H. and Cleveland, D.W. (2018). Tuning apoptosis and neuroinflammation: TBK1 restrains RIPK1. Cell 174: 1339-1341.

Zarnegar, R., DeFrances, M.C., Kost, D.P., Lindroos, P., and Michalopoulos, G.K. (1991). Expression of hepatocyte growth factor mRNA in regenerating rat liver after partial hepatectomy. Biochem. Biophys. Res. Commun. 177: 559-565.

Zettl, M., Adrain, C., Strisovsky, K., Lastun, V., and Freeman, M. (2011). Rhomboid family pseudoproteases use the ER quality control machinery to regulate intercellular signaling. Cell 145: 79-91.

Zhang, D.-W., Shao, J., Lin, J., Zhang, N., Lu, B.-J., Lin, S.-C., Dong, M.-Q., and Han, J. (2009). RIP3, an energy metabolism regulator that switches TNF-induced cell death from apoptosis to necrosis. Science 325: 332.

Zhuang, Y., Xu, H.C., Shinde, P.V., Warfsmann, J., Vasilevska, J., Sundaram, B., Behnke, K., Huang, J., Hoell, J.I., Borkhardt, A., et al. (2020). Fragile $X$ mental retardation protein protects against tumour necrosis factor-mediated cell death and liver injury. Gut 69: 133-145.

Zunke, F. and Rose-John, S. (2017). The shedding protease ADAM17: physiology and pathophysiology. Biochim. Biophys. Acta Mol. Cell Res. 1864: 2059-2070. 